УДК 656.212:656.225

\title{
УДОСКОНАЛЕННЯ КОНСТРУКЦІЇ СОРТУВАЛЬНОЇ СТАНЦІЇ ПРИ ШВИДКІСНИХ ПЕРЕВЕЗЕННЯХ В УМОВАХ ЗМІНЕННЯ ОБСЯГІВ РОБОТИ
}

\author{
Канд. техн. наук В.В. Кулешов, магістр Є.Л. Гронський \\ УСОВЕРШЕНСТВОВАНИЕ КОНСТРУКЦИИ СОРТИРОВОЧНОЙ СТАНЦИИ ПРИ \\ СКОРОСТНЫХ ПЕРЕВОЗКАХ В УСЛОВИЯХ ИЗМЕНЕНИЯ ОБЪЕМОВ РАБОТЫ
}

\author{
Канд. техн. наук В.В. Кулешов, магистр Е.Л. Гронский

\section{IMPROVEMENTS IN THE DESIGN OF THE MARSHALLING YARD FOR HIGH-SPEED} \\ TRANSPORT IN A CHANGING WORKLOAD
}

Cand. of tehn sciences V. Kuleshov, master student E. Gronskiy

Розглянуто технічний розвиток сортувальної станиії Коростень та виконано аналіз роботи за 2011-2014 роки. Показані умови оперативного планування роботи сортувальної станції. Наведена схема одержання інформаиії і планування роботи станиії Коростень.

Синтез нейроконтролера роботи сортувальної станції при швидкісних перевезеннях, на прикладі станиії Коростень, в умовах змінення обсягів перевезень можливо виконати на базі тришарової прямонаправленої мережі. Така технологія забезпечує скорочення тривалості перебування вагонів на сортувальній станиії, тобто має ресурсозберігаючу направленість. В окремі періоди місяия економія експлуатаџійних витрат має коливання 6,1-7,8\%, у середньому 4,42\% від їх фактичних витрат.

Ключові слова: вагон, генетичний алгоритм, модель технологї вантажних перевезень, итучні нейронні мережі.

Рассмотрено техническое развитие сортировочной станщии Коростень и выполнен анализ работы за 2011-2014 годы. Показаны условия оперативного планирования работы сортировочной станщии. Приведена схема получения информащии и планирования работы станции Коростень.

Синтез нейроконтроллера работы сортировочной станции при скоростных перевозках, на примере станции Коростень, в условиях изменения объемов перевозок возможно выполнить на базе трехслойной прямонаправленной сети. Такая технология обеспечивает сокращение продолжительности нахождения вагонов на сортировочной станции, т.е. имеет ресурсосберегающую направленность. В отдельные периоды месяца экономия эксплуатационных расходов имеет колебание 6,1-7,8\%, в среднем 4,42\% от фактических расходов.

Ключевые слова: вагон, генетический алгоритм, модель технологии грузовых перевозок, искусственные нейронные сети.

Considered technical development yard Korosten and the analysis of work for 2011-2014. The conditions of the operational planning of the marshalling yard. The scheme of information and planning of the station Korosten.

Synthesis neyrokontrolera yard work at high-speed traffic, as an example: the station Korosten, under changing traffic volumes may be performed on the basis of a three-layer pryamonapravlennoï network. This technology provides a reduction in length of stay on the wagon yard, ie It is resource-oriented. In some periods of the month savings in operating costs has swings 6,1-7,8\%, on average, $4.42 \%$ of the actual costs.

Keywords: car, genetic algorithm, the model of freight traffic technology, artificial neural networks.

Вступ. Залізничний транспорт України є складною системою технологічних підрозділів і технічних засобів, які повинні забезпечити перевезення вантажів із максимально можливою продуктивністю, мінімальною собівартістю, гарантованою безпекою руху.

$$
\text { Одним iз основних напрямків }
$$

забезпечення конкурентоспроможності 
залізничного транспорту в умовах транспортного ринку та інтеграції до Свропейської співдружності $€$ впровадження ресурсозберігаючих технологій в усі ланки перевізного процесу.

Постановка проблеми у загальному вигляді та іï зв'язок із важливими науковими та практичними завданнями. При структурних змінах і зростанні економіки виникає необхідність адекватно розвивати транспортну систему, для того, щоб вона забезпечувала всі потреби держави й одночасно мала необхідні резерви. Тому необхідно удосконалювати технології роботи сортувальних станцій, а саме станції Ясинувата, в умовах приведення потужності існуючих пристроїв у відповідність до розрахункових обсягів перевезень. Питання удосконалення системи управління парком вантажних вагонів є важливим для подальшого реформування залізничної галузі України.

Аналіз останніх досліджень i публікацій. У нормативних документах $[1,2]$ при організації перевезень докладно не враховані застосування методів моделювання роботи сортувальної станції при швидкісних перевезеннях в умовах змінення їх обсягів. У попередніх дослідженнях [3-6] були розглянуті сучасні підходи до вдосконалення технології перевезень парком вагонів операторських компаній. Але потребують розв'язання питання удосконалення технології роботи сортувальних станцій в умовах розвитку інформатизації при застосуванні методів моделювання технології вантажних перевезень, яка грунтується на основі використання технічних засобів вирішальних сортувальних вузлових станцій 3 оптимізацією їх основних параметрів. Адже основні кількістні та якісні показники погіршились унаслідок неефективних технологій перевезень.

Визначення мети та задачі дослідження. Мета та задачі дослідження удосконалення конструкції сортувальної станції при швидкісних перевезеннях на прикладі станції Коростень, в умовах змінення обсягів роботи.

Основна частина дослідження. Станція Коростень за характером виконуваної роботи $\epsilon$ сортувальною, за обсягом роботи віднесена до позакласної станції, з особливостями технології роботи міждержавної передавальної (прикордонної) сортувальної станції.
I3 загального вагонопотоку, що надходить на станцію, транзитний вагонопотік 3 переробкою складає $67,4 \%$, без переробки $28,2 \%$, місцевих 4,4\%. Добове навантаження складає 43 ваг, вивантаження - 38 ваг. Кількість вагонів у подачі на під’їні колії: ВАТ «Коростенський комбінат хлібопродуктів», AT3Т «Коростенський фарфор», ВАТ «Коростенський завод шляхових машин «Жовтнева кузня», ТОВ «Сокіл», ВАТ «Житомироблпаливо», ВАТ «Хіммаш», ТОВ «Фактор Нафтогаз», «ПП Петренко В.М.», ТОВ «Елізіум пласт», ВАТ «Коростенський завод залізобетонних шпал».

До станції примикає чотири перегони: у непарному напрямку - Коростень - КоростеньЖитомирський - одноколійний; Коростень блок-пост Південний - чотириколійний; у парному напрямку - Коростень - Шатрище двоколійний; Коростень - КоростеньПодільський - одноколійний.

Через станцію Коростень проходить 16 пар пасажирських поїздів дальнього прямування, у т. ч.: 12 пар курсують протягом року, 2 пари пасажирських поїздів курсують в літній період, 2 пари прямують транзитом без зупинки. Із 16 пар: 10 пар належать до категорії швидких поїздів і 6 пар - пасажирські, у тому числі 5 пар поїздів - це пасажирські поїзди міждержавного сполучення (СНД), 2 пари поїздів міжнародного сполучення, 5 пар поїздів підвищеного комфорту. Для прийманнявідправлення і пропускання пасажирських та приміських поїздів на станції Коростень передбачено 2 головні колії станційного парку та 4 колії приміського парку.

Станція має парки: станційний, сортувально-відправний, приміський, Ковельський та вантажний район.

Станційний парк має 11 колій: 10 - для приймання, відправлення, пропускання пасажирських, приміських та вантажних поїздів в обох напрямках, 1 - для відстою недіючих локомотивів, вагонів.

Сортувально-відправний парк складається із 17 колій: 4 - сортувально-відправні для вантажних поїздів у напрямі Сходу та Заходу, 8 - для вантажних поїздів у напрямі Заходу, 2 витяжні, 1 - гіркова, 1 - для відстою вагонів 3 вантажами класу небезпеки 1 (ВМ), затриманих контролюючими службами, 1 - вагова.

Приміський парк має 11 колій: 1 - для приймання, відправлення, безупинного 
пропускання пасажирських, приміських поїздів в обох напрямах та маневрових складів, локомотивів, 3 - для приймання, відправлення пасажирських, приміських поїздів та пропускання маневрових складів в обох напрямах, 2 - відстійні для приміських поїздів, електровозів, 1 - ходова для пропускання пасажирських поїздів, приміських поїздів в обох напрямах, 1 - для відстою приміських поїздів, службових вагонів, 1 - для відстою відбудовного поїзда, 1 - для відстою пожежного поїзда, 1 - з'єднувальна для пропускання приміських дизель-поїздів в обох напрямах та їх відстою.

Ковельський парк у своєму складі має 10 колій: 1 - головна для приймання, відправлення, безупинного пропускання пасажирських, приміських, вантажних поїздів в обох напрямах, 1 - приймально-відправна для приймання, відправлення, пропускання вантажних поїздів в обох напрямах та відстою електропоїздів, 4 - приймально-відправні для безупинного пропускання пасажирських та приміських поїздів, приймання, відправлення, пропускання вантажних поїздів в обох напрямах, 1 - ходова для пропускання локомотивів, відстою електровозів, 2 - відстійна для відстою спецвагонів, 1 - запобіжна.

Сортувальна робота 3 формування та розформування поїздів виконується зі східного боку Сортувально-відправного парку на гірці малої потужності 3 двома гальмовими позиціями. 3 західного боку Сортувально- відправного парку маневрова робота виконується на витяжній колії.

Відправлення $з$ переробкою сортувальної станції Коростень у липні 2014 р. по відношенню до липня 2011 р. зменшилося на 0,8 \%. Відправлення без переробки збільшилось на $16 \%$, відправлення місцевих вагонів збільшилось на 22,4 \%, навантаження зменшилось на $6,9 \%$, статичне навантаження збільшилось на $8,5 \%$, вивантаження збільшилось на 42,3\%, середньодобова остача під вивантаженням збільшилась на 3,4\%, відправлення важковагових поїздів зменшилось на $22,9 \%$, кількість перероблених вагонів зросла на $8 \%$, простій місцевого вагона зріс на $15,5 \%$, простій місцевого вагона під однією вантажною операцією зменшився на 13,8\%, простій транзитного вагона 3 переробкою збільшився на 19,2\%, простій транзитного вагона без переробки зменшився на 45,1\%, простій транзитного вагона у навантаженому стані з переробкою зменшився на 6,8 \%. Аналіз показників відправлення вагонів сортувальної станції Коростень за липень 2011-2014 р.p. наведено на рис. 1. Аналіз простою вагонів сортувальної станції Коростень за липень 20112014 p.p. наведено на рис. 2.

Оперативне планування роботи станції здійснюється 3 метою виконання завдання 3 приймання і відправлення поїздів і вагонів, навантаження i вивантаження, виконання графіка руху, плану формування поїздів i якісних показників роботи станції.

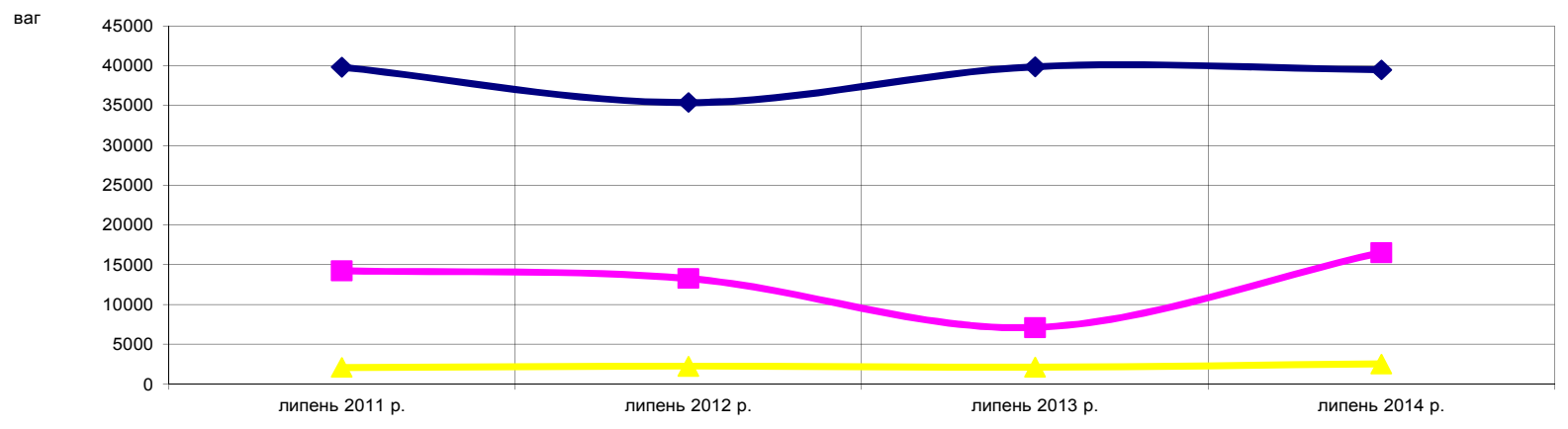

\footnotetext{
$\rightarrow$-Відправлення з переробкою, ваг - -Відправлення без переробки, ваг Відправлення місцевих, ваг
}

Рис. 1. Аналіз показників відправлення вагонів сортувальної станції Коростень за липень 2011-2014 років 


\section{Експлуатація залізниць}

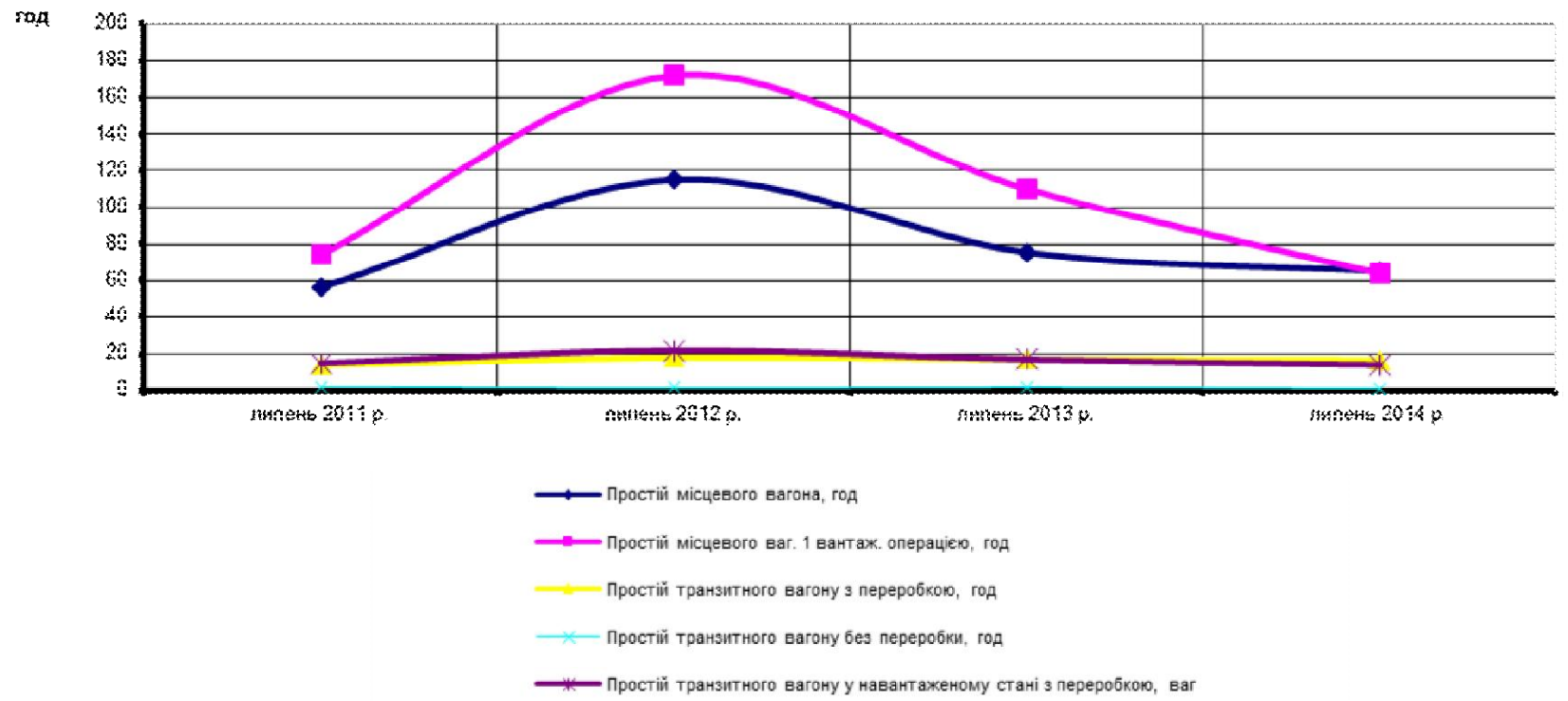

Рис. 2. Аналіз простою вагонів сортувальної станції Коростень за липень 2011-2014 років

Оперативне планування роботи станції здійснюється на добу, зміну і по 4-6 годинних періодах упродовж зміни. Підставою для змінного і поточного планування є інформація про підхід поїздів, вагонів, локомотивів i розрахунок їх наявності, що допускається, на станції до початку планованого періоду.

Умови оперативного планування роботи сортувальної станції:

- оперативне планування поїзної i маневрової роботи станції (на добу і зміну);

- ефективне використання технічних засобів станції, дотримання заходів із забезпечення безпеки руху, маневрової роботи й охорони праці працівників зміни;

- обробка документів у системі АСК ВП Уз-€;

- формування поїздів відповідно до встановленого плану формування поїздів i встановлених норм ваги і довжини;

- ефективне використання маневрових засобів і розподіл їх за районами роботи;

- контроль обліку і звітності роботи станції за основними показниками;

- упровадження нової техніки i технології, направлених на ефективне використання технічних засобів;

- оперативний контроль за використанням i вдосконалення технічних засобів;

- виконання завдань 3 навантаження i вивантаження вантажів;
- здійснення оперативного планування вантажної і комерційної роботи станції;

- виконання завдань 3 простою вагонів під вантажними операціями;

- оперативне керівництво обробкою поїздів і составів у парках станції;

- оперативне керівництво маневровою роботою 3 розформовування $\mathrm{i}$ формування поїздів, з прибирання і подавання вагонів до вантажно-вивантажувальних пунктів, пунктів ремонту вагонів;

- виконання змінного плану 3 приймання, відправлення, пропуску і технічної обробки поїздів, розформовування i формування составів;

- виконання технологічних норм 3 обробки поїздів і вагонів, максимальне поєднання технологічних операцій розформовування, формування i технічної обробки составів у парках станції;

- раціональне розділення роботи між гіркою і сортувальним парком;

- організація роботи станційного технологічного центру обробки інформації $\mathrm{i}$ перевізних документів.

Автоматизовані системи керування (АСК) призначені для:

- автоматизації технологічних процесів роботи станції;

- надання оперативної інформації з метою прийняття управлінських рішень персоналом станції; 


\section{Експлуатація залізниць}

- підвищення рівня достовірності вхідної інформації, станційних звітів, оперативної довідкової інформації, переданої у системи верхнього рівня, за рахунок комплексного логічного контролю.

АСК є системою організаційного управління. Вона функціонує на базі інформації, що вводиться користувачами - працівниками станції (операторами при ДСП, маневрових диспетчерах, СТЦ і товарної контори), а також на базі інформації з інших станцій, яку можна отримати 3 АСК. Схема отримання інформації та планування роботи сортувальної станції Коростень наведено на рис. 3.

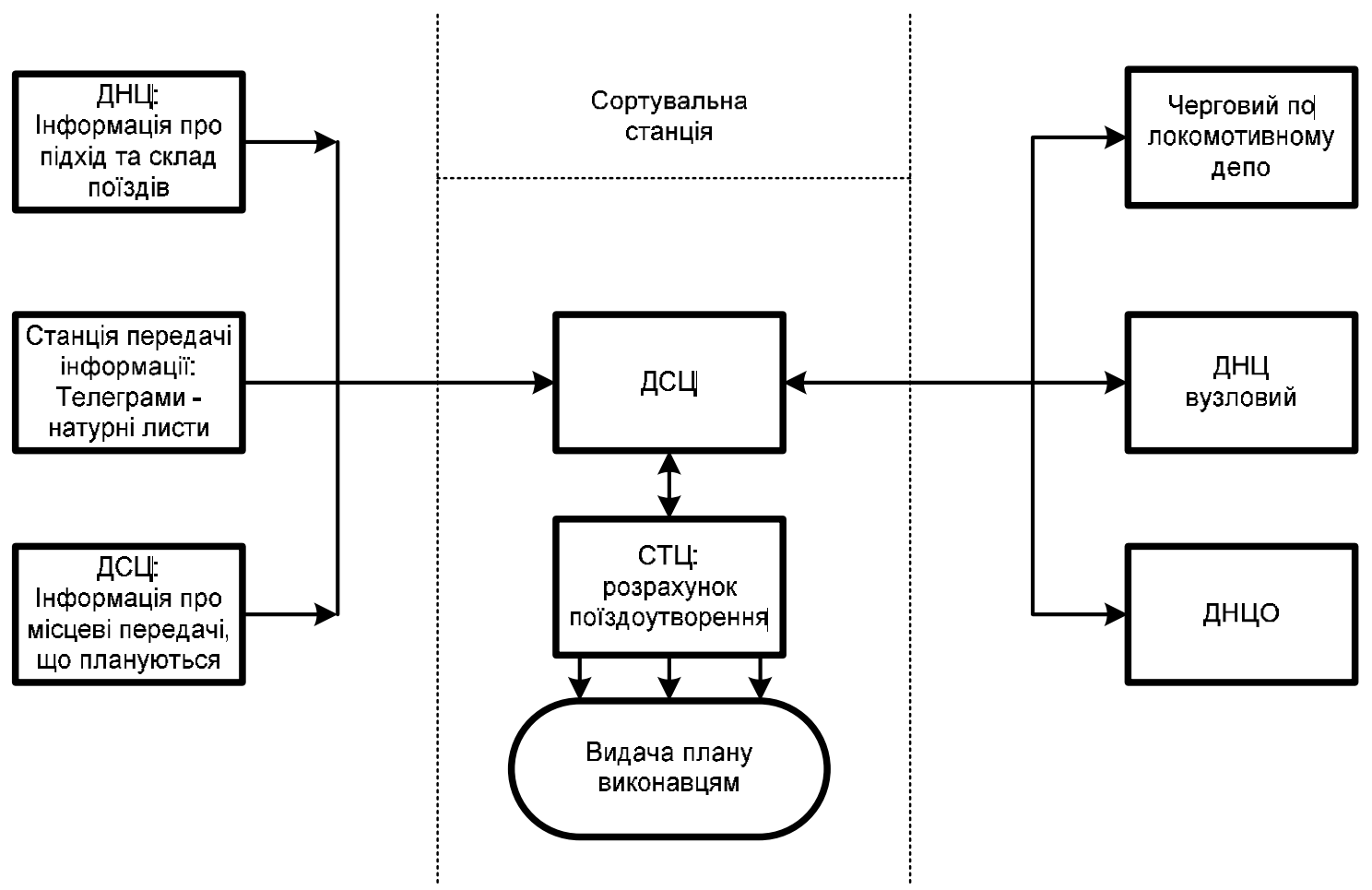

Рис. 3. Схема отримання інформації та планування роботи сортувальної станції Коростень

На станції ведеться два види обліку (звітності): оперативний і статистичний. Оперативний облік ведуть працівники, пов'язані з рухом поїздів у процесі виконання змінних i добових планів перевезень 3 використанням засобів оперативного зв'язку і персональних комп'ютерів. Статистичний облік на основі документів про виконану роботу вагонного парку, норм ваги і довжини поїздів здійснюють працівники відділу обліку станції.

Нейронні мережі являють собою альтернативний напрямок у теорії автоматичного керування, що пропонує інший спосіб відбиття та перетворення дійсності, у якому можна виявити і подібні і різні риси із класичною парадигмою [8].

У системах керування штучні нейронні мережі (ШНМ) можуть застосовуватися у вигляді нейроконтролерів, нейроемуляторів, що імітують динамічне поводження об'єкта керування в цілому або на його окремих характеристиках, які важко піддаються математичному моделюванню.

Синтез нейроконтролера роботи сортувальної станції при швидкісних перевезеннях, на прикладі станції Коростень, в умовах змінення обсягів перевезень можливо виконати на базі тришарової прямонаправленої мережі. Як об'єкт керування можливо вибрати інерційну коливальну ланку другого порядку 3 передатною функцією виду

$$
W=\frac{k}{T^{2} s^{2}+2 T \varsigma S+1} .
$$

Мета керування - заглушення коливань обсягів перевезень при роботі сортувальної станції при швидкісних перевезеннях при 


\section{Експлуатація залізниць}

східчастому вхідному впливі (значення постійних коефіцієнтів $k=1 ; \quad T=0,5 ; \quad \varsigma=0,1$ підібрані так, щоб коливальні властивості в об'єкта були виражені досить чітко).

Структура нейроконтролера: три ретранслювальних вузли у вхідному шарі, чотири схованих вузли із сигмоїдними активаційними функціями та один вихідний. На вхідні нейрони подається різниця між вхідним впливом $u_{r}$ і виходом об'єкта $x_{1}$, iї інтеграл i похідна, а на виході мережі формується керуючий вплив $u$ (рис. 4).

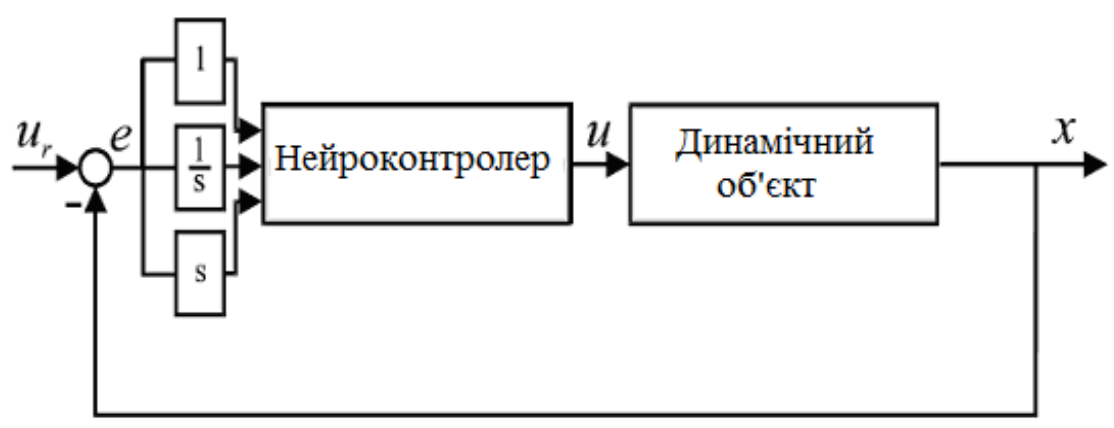

Рис. 4. Робота з нейроконтролером, що апроксимує коефіцієнти пропорційно-інтегро-диференціюючого (ПІД)-регулятора

Для тренування мережі використовують генетичні алгоритми (ГА). Алгоритм зворотного поширення помилки потребує інформації про помилку на ефекторному шарі ШНМ. Для одержання такої інформації в схемі навчання необхідно передбачити обернений нейроемулятор об'єкта, роль якого зводиться до перетворення помилки на виході об'єкта у вихідний сигнал на виході нейроконтролера, що істотно ускладнює процедуру тренування (рис. 5).

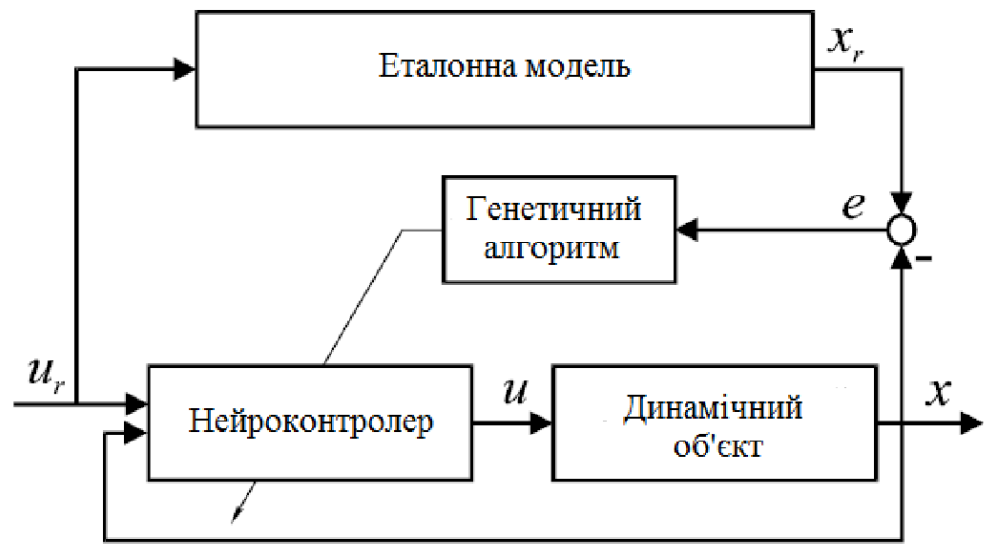

Рис. 5. Застосування ГА для настроювання параметрів нейроконтролера

Генетичний же алгоритм набудовує параметри нейроконтролера не помилково в керуванні $u$, а помилково на виході об'єкта, порівнюючи його з виходом еталонної моделі. Остання втілює в собі уявлення про бажане поводження об'єкта, тобто відіграє приблизно ту ж роль, що і бібліотека тренувальних шаблонів у процедурі тренування.

Після декодування хромосом у вектори змінних оцінювалась здатність кожного варіанта мережі дотримуватись еталонної моделі. Перевірка здійснюється шляхом 
послідовної подачі на керуючий вхід нейроконтролера одиничного позитивного, нульового та одиничного негативного вхідного впливу й обчислення середньоквадратичної помилки вихідної координати об'єкта. Попередньо передатна функція об'єкта керування перетворюється в систему звичайних диференціальних рівнянь у формі Коші [9]

$$
\left\{\begin{array}{l}
\dot{x}_{1}=x_{2} \\
\dot{x}_{2}=\frac{-2 T \varsigma x_{2}-x_{1}+k U}{\sqrt{T}} .
\end{array}\right.
$$

Функціональні цілі при цьому будуть, порівняно 3 типовою технологією, поширені і стосуватимуться, порівняно 3 іншими роботами, енергетичних витрат на не передбачувані маневрові пересування маневрових локомотивів.

Порівняльні діаграми змодельованих та фактичних показників роботи станції Коростень (1-ша декада травня 2015 р.) подано на рис. 6.

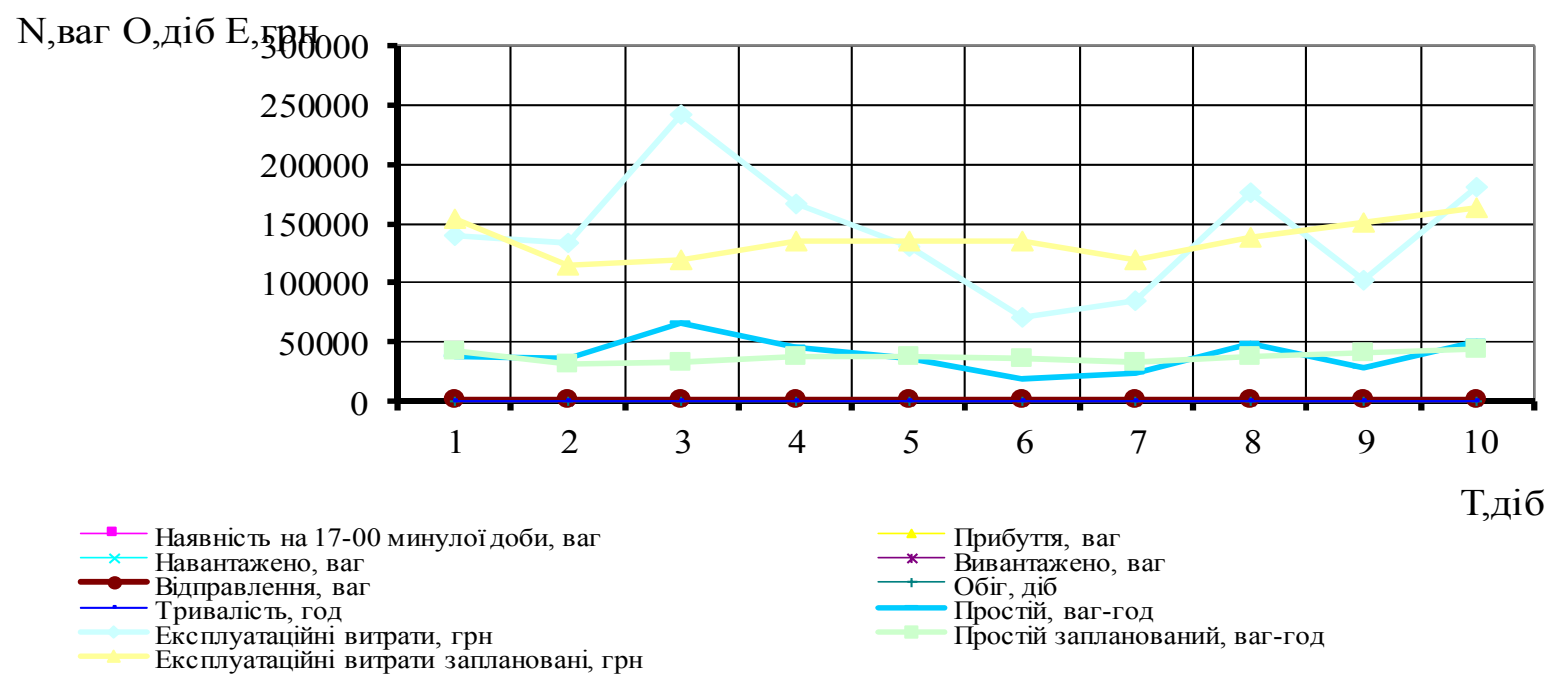

Рис. 6. Порівняльні діаграми змодельованих та фактичних показників роботи станції Коростень (1-ша декада травня 2015 р.)

Така технологія забезпечує скорочення тривалості перебування вагонів на сортувальній станції, тобто має ресурсозберігаючу направленість. В окремі періоди місяця економія експлуатаційних витрат має коливання $6,1-7,8 \%$, у середньому $4,42 \%$ від їх фактичних витрат.

Висновки $з$ дослідження і перспективи, подальший розвиток у даному напрямку. Наявність непродуктивного простою вагонів в очікуванні виконання операцій на сортувальних станціях погіршує ефективність роботи та призводить до додаткових витрат палива, електроенергії та коштів на утримання додаткового рухомого складу, що $\epsilon$ неприпустимим в умовах ринкової економіки.

Одним 3 основних резервів подальшого нарощування обсягів перевезень $\epsilon$ впровадження нових інформаційних технологій на рівні залізниці, дирекції залізничних перевезень (регіонального центру управління перевезеннями), станцій з метою впровадження єдиного технологічного процесу роботи всіх дільниць.

Прискорення обігу вагонів, скорочення тривалості перебування вагонів на сортувальних станціях значно впливає на прискорення доставлення вантажів i 
задоволення потреб користувачів та операторів перевезень.

Заходи щодо вдосконалення сортувальних станцій повинні максимально забезпечити безпеку руху, ресурсозбереження. Завдяки оновленню основних фондів необхідно ліквідувати «вузькі місця» в пропускній та переробній спроможності станції.

Модернізація засобів механізації та автоматизації сортувальної роботи, упровадження інтелектуальних систем управління, а в кінцевому підсумку створення «інтелектуальних сортувальних станцій» повинні базуватися на нових передових технологіях і сучасних розробках. Порівняльні діаграми змодельованих та фактичних показників даватимуть змогу знайти резерви скорочення експлуатаційних витрат на проектування та організацію роботи сортувальних станцій.

\section{Список використаних джерел}

1. Транспортна стратегія України на період до 2020 року [Електронний ресурс]: схвалена розпорядженням Кабінету Міністрів України від 16 грудня 2009 р. №1555-р. - Режим доступу: www/URL: http://www.mintrans.gov.ua/ uk/discussion/15621.html/ 10.12.2009. - Загол. з екрану.

2. Державна цільова програма реформування залізничного транспорту на 2010-2019 роки [Електронний ресурс]: в редакції постанови Кабінету Міністрів України від 26 жовтня 2011 р. № 1106. - Режим доступу: www/URL: http://zakon4.rada.gov.ua/laws/show/1106-2011-п. - Загол. 3 екрану.

3. Данько, M.I. Визначення парку вагонів операторських компаній для забезпечення перевезень вантажів залізничним транспортом [Текст] / М.І. Данько, В.В. Кулешов // Зб. наук. праць. - Харків: УкрДАЗТ, 2004. - Вип. 57. - С. 121-128.

4. Данько, Н.И. Разработка организационно-технологической модели управления парком грузовых вагонов разной формы собственности [Текст] / Н.И. Данько, Д.В. Ломотько, В.В. Кулешов // Инновационный транспорт. Научно-публицистическое издание. - 2012. - №4(5). - С. 8-13.

5. Кулешов, В.В. Удосконалення технології перевезень парком вагонів операторських компаній на станціях вузла [Текст] / В.В. Кулешов, О.Ю. Толбатов, Т.Р. Чурилик // Зб. наук. праць ІППК УкрДАЗТ. - Харків: УкрДАЗТ, 2013. - Вип. 135. - С. 107-113.

6. Кулешов, В.В. Удосконалення інформаційної технології роботи з вагонами різних форм власності з метою оптимізації пропускної спроможності залізничних транспортних систем [Текст] / В.В. Кулешов // Зб. наук. праць УкрДАЗТ. - Харків: УкрДАЗТ, 2011. - Вип. 124. - С. 83-90.

7. Кулешов, В.В. Формування Єдиної технології процесу перевезень операторів рухомого складу на інфраструктурі залізниць [Текст] / В.В. Кулешов // Вагонный парк. - 2014. - № 7(88). C. 4-7.

8. Генетические алгоритмы, искусственные нейронные сети и проблемы виртуальной реальности [Текст] / Г.К. Вороновский, К.В. Махотило, С.Н. Петрашев, С.А. Сергеев. - Харьков: OCHOBA, 1997. - $112 \mathrm{c}$.

9. Шикин, Е.В. Математические методы и модели в управлении [Текст] / Е.В. Шикин, А.Г. Чхартишвили. - М.: Дело, 2004. -437 с.

Рецензент д-р техн. наук, професор О.М. Огар

Кулешов Валерій Вячеславович, канд. техн. наук, доцент кафедри залізничних станцій та вузлів Українського державного університету залізничного транспорту. Тел.: (057) 730-10-42. E-mail: kharkov-

kuleshov@mail.yandex.ua.

Гронський Свгеній Леонідович, слухач Навчально-наукового інституту перепідготовки та підвищення кваліфікації кадрів Українського державного університету залізничного транспорту. Тел.: (057) 730-10-42.

Kuleshov Valeriy Vaycheslavovich, $\mathrm{PhD}$. Sc., assistant professor of railway stations and junctions Ukrainian State University of Railway Transport. Tel.: (057) 730-10-42. E-mail: kharkov-kuleshov@mail.yandex.ua.

Hronskyy Eugene Leonidovich, Listener Training and Research Institute of retraining and advanced training of Ukrainian State University of Railway Transport. Tel.: (057) 730-10-42.

Наукова праця здана до друку 01.07.2015 року 